\title{
Online Temptations: Divorce and Extramarital Affairs in Kazakhstan
}

\author{
Jasmin Dall' Agnola $^{1}$ (D) and Hélène Thibault ${ }^{2, *}$ (D) \\ 1 Department of Social Science, Oxford Brookes University, Oxford OX3 0BP, UK; jasmindallagnola@gmail.com \\ 2 Department of Political Science and International Relations, School of Sciences and Humanities, \\ Nazarbayev University, Nur-Sultan 01000, Kazakhstan \\ * Correspondence: helene.thibault@nu.edu.kz
}

Citation: Dall'Agnola, Jasmin, and Hélène Thibault. 2021. Online Temptations: Divorce and Extramarital Affairs in Kazakhstan Religions 12: 654. https://doi.org/ $10.3390 /$ rel12080654

Academic Editor: Jan Jaap de Ruiter

Received: 24 June 2021

Accepted: 9 August 2021

Published: 18 August 2021

Publisher's Note: MDPI stays neutral with regard to jurisdictional claims in published maps and institutional affiliations.

Copyright: (c) 2021 by the authors. Licensee MDPI, Basel, Switzerland. This article is an open access article distributed under the terms and conditions of the Creative Commons Attribution (CC BY) license (https:// creativecommons.org/licenses/by/ $4.0 /)$.

\begin{abstract}
In recent years, the institution of marriage in Muslim Central Asia has undergone profound transformations in terms of religious dynamics, migration patterns, and the impact of globalization. In Kazakhstan between 2014 and 2019, every third marriage ended in divorce. By examining how Muslim Kazakhs' support for divorce and casual sex is related to their consumption of information obtained on the Internet, mobile phone, and social media, this study contributes to the growing body of literature on the transformative forces of information and communication technology (ICT) in Kazakhstan and Central Asia. It uses a mixed-method approach that contrasts wider statistical trends from the World Values Survey Wave 7 country dataset on Kazakhstan with empirical data from focus groups conducted in five different regions of the country in 2019, involving a total of 96 respondents. The findings from the statistical and non-statistical analysis show that frequent exposure to information online influences Muslim Kazakhs' support for extramarital affairs and divorce. Yet, frequent use of ICTs does not necessarily weaken the institution of marriage. Apart from its effect on university-educated female Kazakh youth, it seems to reinforce traditional understanding of marriage obligations among older generations and young men.
\end{abstract}

Keywords: divorce; Islam; information and communication technologies; Kazakhstan

\section{Introduction}

In Muslim Central Asia, marriage ceremonies called tuys or toys are known for being lavish and for playing important social functions related to prestige and social status. Yet, the institution of marriage is undergoing profound transformations related to religious dynamics, migration patterns, and the impact of globalization (Cleuziou and McBrien 2021). In Kazakhstan, young people marry in great numbers. If they marry early, they also divorce early. Most divorces (61.5 percent) take place in the first decade of marriage and the first four years of marriage account for a third of all divorces (KISD 2020, p. 294). According to the UN Demographic UN Demographic Yearbook (2019), Kazakhstan has one of the highest divorce rates worldwide. Between 2014 and 2019, every third marriage ended in divorce.

So far, there is little research on the question of what impact the popularization of information and communication technology (hereafter ICTs) has on Kazakhstan's rising divorce rate. Poor Internet penetration via fixed connections and a lack of infrastructure make mobile headsets and smartphones an easy on-the-go option to access social media. Thus, especially since the wider availability of cheaper 3G and 4G mobile technologies in the 2010s, the broader public in Kazakhstan has access to global social networks (such as Instagram and Facebook). As a result, Kazakhstanis ${ }^{1}$ have an easy access to content that promotes values, narratives, and cultural practices that challenge dominant local family values, such as content showing and/or legitimizing extramarital affairs and casual sex. There is little research to date on how exposure to content online may affect the wider population's understanding of divorce and casual sex in Kazakhstan. The purpose of this 
study is to examine and understand how Muslim Kazakhs' exposure to information and content online through ICTs affects their approval of divorce and casual sex. As a case sui generis, this paper uses a partially mixed sequential equal status mixed-method design that confronts wider statistical trends identified from the World Values Survey Wave 7 (Haerpfer et al. 2020) country dataset on Kazakhstan Today (2018) with empirical data from 20 focus groups conducted in the Aktau (4), Almaty (4), Astana (6), Kyzylorda (3), and Shymkent (3) regions of Kazakhstan in 2019, in which a total of 96 respondents were involved. In this paper, we use the UN Demographic UN Demographic Yearbook's (2019) definition of divorce as the legal "separation of spouses that confers on the parties the right to remarriage under civil, religious and/or other provisions, according to the laws of each country".

The paper is divided into four sections. In the first, we provide some historical and socio-political context to issues relating to Islam, family values, and ICTs use in Kazakhstan. It allows the reader to make sense of the current dynamics and underline the conflicting narratives about divorce and casual sex within different socio-economic circles which generate intense societal debates on- and offline. Second, the methodological approach employed and some of its shortcomings are discussed. Third, we proceed with the statistical analysis and reveal a strong correlation between frequent social media exposure and Muslim Kazakhs' approval of divorce, as well as Muslim Kazakhs' frequent use of the Internet and their acceptance of casual sex. We then proceed to juxtapose the quantitative results with our own qualitative data and reveal that the discourses expressed by various participants confirm that the power of Kazakh family values and religion relating to marriage and divorce practices run deep. Apart from university-educated Kazakh youth, older respondents argued that time spent on ICTs has a negative influence on contentment and commitment in marriage because people are exposed to online temptations and therefore are more likely to cheat on their spouses.

\subsection{Islam and Family Dynamics in Contemporary Kazakhstan}

Religious and family dynamics in Kazakhstan remain heavily influenced by the legacy of the Soviet atheist modernization and the female emancipation project that shook the traditional organization of communities living in the USSR from its early beginning (Torno 2017). In 1917, the revolutionary Bolshevik government was one of the first in the world to grant women the right to vote, to divorce, and to perform abortions (Northrop 2004, p. 9). In the absence of a proper proletarian class in Central Asia, Marxist ideologues viewed Muslim Central Asian women as a "surrogate proletariat" because of their subaltern position within the patriarchal structure of both the society and the family (Northrop 2004, p. 12). Female emancipation from patriarchal norms was a noble goal that the Bolsheviks prided themselves on, but it was also conveniently meant to undermine the influence of Islam and the Muslim clergy in Central Asia. Traditional Muslim institutions such as waqfs (religious endowments) were dismantled and traditions, including polygyny, were outlawed in the early 1920s (Keller 2001, p. 50). Today, polygyny remains illegal in all Central Asian states with the exception of Kazakhstan, which decriminalized it in 1998. The rationale behind this legal change might be related to the fact that polygyny is practiced by a number of high-profile politicians in Kazakhstan who needed to decriminalize and somehow legitimize their relationships (Sagadiyeva 2021). Finally, the Soviet project of female emancipation was grounded in strong heteronormative norms that favored monogamy and a conservative approach to sexuality. ${ }^{2}$ Even though classical Marxism saw the family as a bourgeois institution that was instrumental in class reproduction, in the USSR, the authorities relied heavily on it as a means of social organization (Zhdanko and Basayeva 1990). Formal gender equality was achieved in the sense that women almost had equal rights and were active in the public sphere, but the workforce and social dynamics remained overall very gendered. Kandiyoti (2007) argues that female emancipation in the USSR led to a paradox. On the one hand, women were part of the labor force and enjoyed 
legal protection but on the other hand, they were praised for their feminine, maternal qualities and most importantly, they faced unchanged domestic division of labor at home.

Like many postcolonial nations, Kazakhstan's independence in 1991 led to major transformations, including the redefinition of socio-economic and political values devoid of socialist content and propaganda. Nation-building efforts included the promotion of national, traditional values that seemed to redefine the gender order established during the Soviet Union (Arystanbek 2020; Cleuziou and Direnberger 2016; Kudaibergenova 2018). Given that Kazakhstan was the only Central Asian republic where the titular nation did not constitute the majority of the population, discourses celebrated motherhood in a context where fertility rates were plummeting due to the difficult economic transition in the 1990s. Even though women around the world face pressure to conform to dominant heteronormative standards of femininity and purity, it becomes particularly acute in Kazakhstan given the nation-building process (Kudaibergenova 2019). Female bodies are subjected to scrutiny and critique and imposed conformity to local understanding of proper female behavior, defined as caring and modest. When it comes to marriage, nationalist discourses emphasize the importance for women to remain virgin until marriage (Kudaibergenova 2019). Despite that, a 2018 study showed that about a third of the Kazakhstani teenagers (15-19 years old) surveyed had sexual experience and 57 percent of 19-year-olds were sexually active (Zhulmukhametova 2018). Conformity is imposed through uyat, which translates as "shame". Uyat can be understood as a cultural practice that consists in shaming an individual who has deviated from the norm and done something deemed shameful by the rest of the community. Traditionally used as a form of socio-political self-regulation, its reminiscence in the 21st century has evolved into a form of moral policing, mostly imposed on women (Khegai 2020). Even though not part of any official policies, some state discourses and practices contribute to the reinforcement of this culture of modesty, purity and obedience, and shame. Given how Kazakhstani communities remain tightly knit and how extended families and kinship networks depend on each other for social and economic support, the culture of shame is an efficient way to discipline individuals. Kinship ties, which refer to relationships of affinity, usually play an important role in the regulation of Central Asian communities and may continue to play a coercive role in the choice of a spouse today (Cleuziou and McBrien 2021). However, migration patterns, the retreat of the welfare state, and the advancement of capitalist economies contribute to reorganize solidarity networks in Central Asia. Some authors claim that economic imperatives have become increasingly determinant, even at the detriment of kinship, when it comes to finding a suitable spouse (Cleuziou 2021; Borisova 2021). In the context of Kazakhstan, we will argue that the use of ICTs also challenges traditional marriage arrangements.

Marriage and family remain strong institutions and an overwhelming majority (82.5 percent) of young people in Kazakhstan (14-29) envision their future as married with kids (Friedrich Ebert Foundation Report 2019, p. 50) and their answers match the very high marriage rate in the country. In 2017, the country registered 7.9 marriages per each 1000 inhabitants (a rate that is higher than most OECD countries ${ }^{3}$ ). Family, nuclear and extended, remains a very strong institution. In a 2020 survey conducted in all regions of Kazakhstan, 73.1 percent of those surveyed answered that they considered family to be the meaning of life. Interestingly, 75.1 percent of women believed that the family was the meaning of life, whereas for 51.3 percent of men, reproduction was (Forbes 2020). Yet, despite people's belief in marriage and family life, divorce rates are high and nearly 40 percent of marriages end up in a divorce (Smayyl 2020). According to a 2020 survey conducted among 3000 respondents by the Institute of Equal Rights and Equal Opportunities of Kazakhstan and the Center for Support of Civil Initiatives asking respondents what they thought were the reasons why people divorced, in the first place (61 percent) was "the intervention of relatives", followed by "permissiveness" (41 percent), "crisis of family values" (36 percent), "selfishness" (28 percent), the influence of social networks (28 percent), and "ease of divorce procedures" (25 percent) (Nurbai 2020). The study found that in particular women are now more likely to file for divorce than men. According to this study, therefore, there exists an 
assumption that the utilization of ICTs and social media in particular increases the number of divorcees in Kazakhstan. Yet, another survey also conducted in 2020 by the Kazakhstan Institute of Public Development with 1200 respondents provided quite different results. Most respondents identified domestic violence as the main reason (43.2 percent), followed by alcoholism ( 39.7 percent) and cheating ( 35.85 percent). Parental interference came in the fourth last position with only 4.4 percent (KISD 2020, p. 296). It seems difficult to explain with certainty why the results are so different, but we can speculate that it has something to do with the formulation of the question asked: "What reason can justify divorce?" which refers not to the actual reasons of divorce but to idealized justifications. This is most probably because most Kazakhstanis hold negative perceptions of divorce. Understandably, divorce is not seen as something positive since, by its own nature, it implies the failure of two individuals to build a long-lasting love relationship. KISD's survey shows that 43.2 percent of respondents considered divorce unacceptable and 45.1 percent had a negative attitude towards divorce but that it was sometimes preferable to constant conflicts (KISD 2020, p. 392).

Divorce laws are fair on paper and recognize the obligations of both spouses, including the payment of alimonies but an important number of men seem to evade this obligation and many single mothers struggle financially (Sakhova 2020). Since marriage is a social as much as it is an economic institution, the COVID-19 pandemic has greatly impacted divorce rates which dropped drastically in one year. Kazakhstani authorities recorded 59,800 divorces in 2019 in comparison to only 22,500 in 2020 (Khabar 2021). We can speculate that the difficult economic conditions combined with the overall uncertainty created by the pandemic contributed to this important reduction of the number of divorces. Interviews and focus groups have revealed that divorce is no longer a strong taboo in Kazakhstan since it is so common. Yet, social stigma continues to affect unmarried and childless individuals whose lifestyle is seen as a failure or a manifestation of selfishness.

The high number of divorces has contributed to the emergence of unexpected dating and matrimonial arrangements such as the increase in the number of polygynous unions in Kazakhstan. Because polygyny is tolerated but not fully legal, it is difficult to get a precise picture. If polygyny is strongly associated with Islam, it appears that most people who practice it are not necessarily practicing Muslims. Among them, many are divorcees who seek a new partnership in which they will retain some independence and not be subjected to the influence of in-laws since most polygynous men do not live with many wives under one roof (Thibault 2021).

The fact that these discourses are met with practices that contradict those ideal representations of marriage reveals something about ongoing battles over female bodies and family values in Kazakhstan. The following section introduces the key points of contention underlying the current scholarly debate on ICTs' transformative potential with regard to dating and marriage arrangements in the Muslim world and in the context of Kazakhstan in particular.

\subsection{ICTs and Extramarital Affairs in Muslim Central Asia}

Especially in the last ten years, sociologists and political scientists have sought to describe and understand the power and role of information and communication technologies (hereafter ICTs) in shaping and influencing people's values and norms around the globe. ICTs, as defined to include broadband Internet, smartphones, and social media platforms in this article, have become an indispensable part of everyday life for people all over the world. In 2020, almost half a billion users joined social media, taking the global total to 4.2 billion in early 2021 (We Are Social 2021). In the same period, the number of mobile phone users and broadband subscriptions increased by 93 million and 316 million. During the COVID-19 pandemic, the number of social media users increased by 2.5 million (+26 percent) between January 2020 and 2021 in Kazakhstan (Kemp 2021). However, whereas Internet penetration followed the global trend and increased by 5 percent, the number of mobile connections in Kazakhstan decreased by 1.2 million (-4.8 percent). 
Previous scholarly literature on ICTs offers useful insights into how digital interpersonal interactions have changed people's dating and mating behavior (Valenzuela et al. 2014; Carter 2016; Zheng et al. 2017). According to ICTs advocates, online dating platforms enable the discussion of wider and more sensitive issues that are often deemed unsuitable in offline settings (Nguyen 2020). Moreover, in the Muslim world, social media platforms and chat rooms create new virtual public spaces where people can meet and engage with the opposite sex without breaching any cultural or religious behavior codes that could damage especially the woman's reputation (Lo and Aziz 2009; Sotoudeh et al. 2017; Kikuta 2019). Some optimists go as far as to argue that ICTs enable youth to pursue love as a basis of marriage and defy the norms of arranged marriage in socially conservative non-Western societies (Chakraborty 2012; Pourmehdi 2015; Kikuta 2019).

Yet, skeptics find that new communication technologies do not only facilitate dating and bonding among people, but also reduce relationship satisfaction by providing potential romantic alternatives and deflecting time and emotional investments away from the committed relationship (Valenzuela et al. 2014; Carter 2016; de Lenne et al. 2019; Fizza and Humaira 2019; Sharifinia et al. 2019). Given its easy access, affordability, and anonymity, ICTs are offering a new avenue for sexual activity online such as flirting, partner seeking, and cybersex (Zheng et al. 2017). A study conducted in the United States concluded that the use of social networks "is negatively correlated with marriage quality and happiness, and positively correlated with experiencing a troubled relationship and thinking about divorce" (Valenzuela et al. 2014, p. 94). Another study run in China found a positive correlation between mobile phone penetration and the divorce rate during the period 2001-2016 (Zhang et al. 2018). Even though phone penetration could simply be a proxy variable for economic well-being, the authors specifically argue that the use of mobile phones and social media platforms can affect people's interpersonal communication and relationships between couples. In reducing the searching costs for extra-matrimonial affairs, ICTs seem to increase the number of extramarital affairs in the US and China.

Similar observations were reported by scholarship in the Muslim world. Sharifinia et al. (2019), in their study on married students in Iran, found that married people's addiction to social networks has a negative influence on their marital commitment and can lead to "emotional divorce" and in some cases to actual divorce. Fizza and Humaira (2019) argue that frequent consumption of social media platforms can have a negative influence on Pakistanis' marital satisfaction, when they follow or spy on their partner's Facebook activities and as a result develop strong sentiments of jealousy of their spouse's Facebook friends. The Internet has also facilitated the creation of online platforms such as polygamy dating platforms that challenge the concepts of monogamous heterosexual marriage and the nuclear family and provide a space for the expression and support of counter discourses of marriage (Sweet-McFarling 2014).

A research agenda is slowly being developed by scholars of Central Asia but so far only very few studies have investigated the importance of mobile Internet connection in altering mating, marriage, and divorce practices in Central Asia. Kikuta (2019) illustrates how the use of smartphones is changing courting and marriage arrangements among Muslim youth in the populous Ferghana Valley in the eastern part of Uzbekistan since the second half of the 2000s. The opportunity to privately communicate on text messaging apps on their mobile phones "far from their parents' prying eyes" helps young Uzbeks expand their independence and self-determined lifestyle and, in doing so, to choose their own spouses (Kikuta 2019, p. 188). Yet cheaper 3G and 4G mobile handsets and smartphones not only help to deepen the bond between a couple, but also to cut it in Central Asia. Some "Uzbek Don Juans" make use of their phones to seduce married women in the absence of their husbands, who work in Russia. As a result, the number of Muslim wives cheating on their husbands has dramatically increased in the Ferghana Valley of Uzbekistan in the 2010s (Kikuta 2019, p. 193). In Kazakhstan, especially among the generation (30+ and mid-40s) who were born and partly socialized in the Soviet period, ICTs and social media platforms in particular are identified as unsafe and highly sexualized digital environments 
that need to be controlled and censored by the state to preserve and protect traditional family values (Dall'Agnola 2020). Conservative circles' fears seem to be justified, because the COVID-19 pandemic has shed light on a new trend in Kazakhstan: male sex workers using online advertising to offer services to local women (Titova 2020). This phenomenon seems to be limited to urban centers and testifies to particular gender dynamics in the country; Thibault (forthcoming) addresses the growing phenomenon of online sex-work in Kazakhstan, in particular, of males offering heterosexual services to females. She argues that women's decision to buy sex via online advertisement is explained by the fact that women's desire for sexual emancipation is constrained by conservative views surrounding female sexuality. In these conditions, transactional sex with "professionals" is a safer option than engaging in casual sex with acquaintances or strangers via online dating which entails some kind of public visibility.

Finally, ICTs not only reduce the searching costs for casual sex and extra-matrimonial affairs, but access to the Internet also plays a fundamental role in obtaining information related to divorce laws and practices and in doing so might help to facilitate divorce (Zheng et al. 2019; Kabatova 2019b). For example, it became a common practice for Tajik labor migrants in Russia to divorce their wives in Tajikistan by sending a mobile phone text message or just making a phone call saying talaq (an Islamic term for a declaration of divorce) (Sulaŭmonn 2020). Sunni Islamic traditions allow men to divorce their wives by merely saying talaq between one and three times. Amid the growing numbers of SMS divorces in Tajikistan, Tajik religious leaders spoke up and issued a fatwa banning the practice in April 2011 (Sulaĭmonn 2020). Yet, so far, Tajikistan has no law that criminalizes SMS divorce.

In short, the existing scholarship on the Muslim world and Central Asia indicates that the use of ICTs can be expected to magnify people's likeliness to engage in casual sex and to file for divorce, because it reduces the searching costs for extramarital affairs and it minimizes the expenses for divorce. We therefore agree with previous scholarship on Central Asia (Kikuta 2019; Nurbai 2020; Sulaĭmonn 2020; Thibault forthcoming) that argues that ICTs not only shape consumption patterns and beauty standards but may also shape Central Asian people's understanding of mating and marriage practices. This leads us to hypothesize that the frequent exposure to ICTs influences, in some cases, even increases Muslim Kazakhs' approval of divorce and casual sex.

\section{Methodology}

\subsection{Regressions}

The objective of the quantitative analysis is to test whether frequent exposure to information on ICTs - the independent variable—affects Muslim Kazakhs' acceptance of divorce and casual sex - the dependent variables. Data were drawn from the World Values Survey Wave 7 (Haerpfer et al. 2020) country data file on Kazakhstan. Overall, the survey involved 1200 respondents, but since the focus groups only featured Muslim Kazakhs, we narrowed this down to focus only on respondents who identified as ethnic Kazakhs and Muslims as well as those who have answered the necessary questions (a total of 578 and 569 respondents for divorce and casual sex). The survey was conducted in interviewees' choice of Kazakh or Russian by the local staff of the Public Opinion Research Institute in Astana (since 2019, Nur-Sultan). The survey took place in October and November 2018 and covered all five regions of Kazakhstan: North Kazakhstan, Central Kazakhstan, West Kazakhstan, South Kazakhstan, and East Kazakhstan, as well as the three cities with republican statusAstana (capital), Almaty, and Shymkent. Respondents comprised individuals aged 18 and older. The sampling procedure was designed to capture a representative sample of Kazakhstan's adult population. The data were collected using a multistage stratified sampling method. The stratification was based on territorial-administrative units and rural and urban populations. Households were selected randomly within each stratum.

The questionnaire items chosen to capture Kazakhs' approval of divorce and casual sex (our dependent variables) were: "Whether you think it can always be justified, never 
be justified, or something in between, using this card. Divorce?" and "Whether you think it can always be justified, never be justified, or something in between, using this card. Having casual sex?" Respondents' answers to the two questions were captured in a ten-point Likert scale from 1 (=not justified) to 10 (=justified). ${ }^{4}$

Additionally, the models included a variety of controls, reflecting the findings in the previous literature on how people's interaction with social media pages influence their views on marriages and divorce in Kazakhstan (Blum 2016, 2019; Dall'Agnola 2021; Zheng et al. 2017; Kikuta 2019; Friedrich Ebert Foundation Report 2019; Kabatova 2019a; Nurbai 2020). Variables consistently found by those previous studies to be associated with Kazakhs' concerns about divorce and casual sex are age, with younger people being more open towards sexual liberation and divorce because they are more frequently exposed to content on social media platforms; gender, with Kazakh men being less tempted to file for divorce than women, but being more likely to engage in online sexual activities with other women; urban/rural and class, with urban middle-class Kazakhs being more likely to file for divorce and engage in casual sex than their working-class counterparts living in the countryside; marital status, with married people being more likely to engage in online sexual activities than singles ${ }^{5}$; and having children, capturing respondents' number of children.

In the statistical analysis, the critical independent variable is Muslim Kazakhs' exposure to information on ICTs. To assess the information outlets and sources respondents consume on a daily, weekly, monthly, and less than monthly basis, or never, respondents were asked to rate how frequently they access information on the Internet, their smartphone, and social media. Unfortunately, the WVS only allowed us to capture Kazakhs' exposure to information on ICTs more broadly and not specifically for the different social media platforms. Yet, according to the Central Asian Barometer survey wave 4 (which was conducted in the same period as the WVS, namely in October and November 2018), Kazakhs' favorite social media platform was Instagram in autumn 2018, with the exception of the generation 50+ who preferred WhatsApp and Odnoklassniki over Instagram (for more details, see Figure A1 in the Appendix A). Next, respondents' answers were changed into binary variables, with daily and weekly exposure to ICTs combined into the category frequently exposed and the remaining ones into not (frequently) exposed. Another shortcoming which needs to be addressed here is that the WVS questionnaire did not include a question about what kind of information respondents are consuming online. Nevertheless, the statistical component is valuable and necessary because it allows us to identify general trends that can be confronted with the empirical data from focus groups in a second step.

\subsection{Focus Groups}

The focus groups were conducted by both authors as part of two separate research projects between June 2019 and January 2020 in different regions of Kazakhstan. The recruitment methods, size, and composition of the focus groups differed slightly. Scholar \#1 is a foreigner who visited Kazakhstan as part of data collection for her doctoral dissertation on the impact of globalization, including ICTs, on national identities in Kazakhstan. Scholar \#2 is a foreigner who works and resides in Kazakhstan. Her focus groups were part of a research project examining marriage and polygynous relations in Kazakhstan and Kyrgyzstan. Even though divorce and ICTs were not the primary topics of the focus groups, discussions around those themes were very frequent and we decided to use this material to put the World Values Survey's results to the test of qualitative inquiry.

Scholar \#1's focus group participants were successfully recruited in the field through existing and associated contacts and through so-called "insider" recruiting (Krueger and Casey 2015, p. 85). Insiders recruited their relatives, friends, and working colleagues. Using pre-existing social groups allowed the incorporation of diverse participants (students, professionals, entrepreneurs, office workers, market salespersons, nurses, etc.) and facilitated a generally relaxed atmosphere during the interviews. 
Scholar \#2's focus groups were organized through a third-party organization located in Nur-Sultan called Data Hunters. The firm specializes in marketing and social research and recruited participants through their established networks. Therefore, participants did not know each other except for one group in Almaty, in which two female friends participated, and one in Kyzylorda, in which a mother and her son participated. The focus groups held with students at Nazarbayev University were conducted by two research assistants to avoid any discomfort since Scholar \#2 is a professor at this University. We acknowledge that our identity as foreign scholars might have had an impact on the nature of the discussions held. Participants might have assumed us to hold "liberal" values and might have refrained from expressing ideas that they thought would have been unpopular with us. However, due to the variety of positions expressed during the focus groups, we believe this was not the case. All focus groups were conducted in Russian with the exception of some conversations partly held in Kazakh in Kyzylorda and Shymkent. Even though this might be seen as a drawback since Russian was some of the participants' second language, we think that on the contrary, the fact that the conversations were held in Russian might have represented an opportunity for participants to speak more freely about topics related to gender relations and sexuality. Indeed, in Kabatova's focus groups speaking about sex education with teenagers, participants were more comfortable to discuss such topics if they spoke in Russian instead of Kazakh, a language some deemed too noble to talk about sexuality (Kabatova 2019b).

Most of the focus groups organized for this research consisted of six or fewer persons, mainly because often a few vocal individuals belonging to the older generations not only dominated group discussions, but sometimes even denounced younger participants and, in doing so, influenced their answers. Particularly while discussing how traditions and cultural practices of Kazakhs may change through their exposure to Western culture on social media, Kazakh youth either chose to agree with the view voiced by older interview participants or to remain silent and not to answer the question at all. This was to comply with the Kazakh convention of uvazheniia $k$ starchim (a Russian expression meaning "to show respect to one's elders") (Blum 2016, p. 112). Thus, younger participants often felt too intimidated to share sensitive personal ideas within a larger group of people. Under those circumstances, conducting smaller focus groups (with two or three participants) to obtain the youth's viewpoint, which unsurprisingly differed significantly from their parents' and grandparents', seemed a sensible approach. To check for possible gender and "respect for elders" biases, in addition to big mixed-age and mixed-gender focus groups, local agents and recruiting offices were instructed to organize small focus groups (with 2-3 participants). Moreover, to control for the liberal versus conservative values divide on sexual liberation (Isaacs 2019), interviews in five different regions of Kazakhstan were conducted: in Nur-Sultan and Almaty, cosmopolitan urban centers that due to their global interconnectedness are known to be more tolerant of sexual diversity (Isaacs 2019); it seemed sensible to additionally conduct focus groups in Kyzylorda and Shymkent, located in South Kazakhstan, a region normally perceived to be the most socially conservative in Kazakhstan. For instance, during the boy band Ninety One's 2016 tour in Kazakhstan ${ }^{6}$, young men in Kyzylorda and Shymkent made use of social media to organize protests asking the authorities to prevent the band's concerts in their cities (Isaacs 2019); and finally, in Aktau, which, due to its geographical position on the eastern shore of the Caspian Sea, is now a center for oil and gas fields and therefore is more exposed to foreign labor and expats working in the oil and gas sector than the four other cities. For more details regarding the composition of the focus groups, see Table 1 below. Ages ranged from 19 to 60 years old. With only a few exceptions of participants of Russian descent in Nur-Sultan and Almaty, all participants identified as Kazakhs. This selection bias was unintentional but reveals something about the ethnic impermeability of social networks. 
Table 1. Overview of focus groups.

\begin{tabular}{ccccc}
\hline Place & Date & Focus Group & Gender & Generation \\
\hline \multirow{5}{*}{ Aktau } & 19 July 2019 & FG1 & 2 females & 19 and 20 years old \\
& 20 July 2019 & FG2 & 4 females, 1 male & 24-28 years old \\
& 20 July 2019 & FG3 & 2 males & 30 and 33 years old \\
& 20 July 2019 & FG4 & 3 females & 30-49 years old \\
\hline \multirow{5}{*}{ Almaty } & 17 June 2019 & FG5 & 3 females & 18-29 years old \\
& 27 October 2019 & FG6 & 4 females, 4 males & 30-49 years old \\
& 27 October 2019 & FG7 & 6 females, 1 male & 30-50 years old \\
& 28 October 2019 & FG8 & 5 females & 30-49 years old \\
\hline \multirow{5}{*}{ Nur-Sultan } & 19 October 2019 & FG9 & 3 males, 3 females & 22-60 years old \\
& 19 October 2019 & FG10 & 6 females & 22-47 years old \\
& 20 October 2019 & FG11 & 6 males & 22-44 years old \\
& 28 January 2020 & FG12 & 6 females & 18-21 years old \\
& 29 January 2020 20 & FG13 & 5 males & 18-21 years old \\
Kyzylorda & FG14 & 3 males, 3 females & 18-21 years old \\
& 2 November 2019 & FG15 & 3 males, 3 females & 21-47 years old \\
& 2 November 2019 & FG16 & 6 females & 22-45 years old \\
& 3 November 2019 & FG17 & 6 males & 22-42 years old \\
\hline \multirow{6}{*}{ Shymkent } & 13 July 2019 & FG18 & 1 male, 3 females & 40-58 years old \\
& 13 July 2019 & FG19 & 2 females & 28 and 43 years old \\
& 14 July 2019 & FG20 & 2 females & 23 and 29 years old \\
\hline
\end{tabular}

\section{Statistical Analysis}

Prior to the presentation of the regression analysis, it is worth looking at how rates of Internet and social media penetration have grown in Kazakhstan in recent years as well as how often Kazakhs who participated in the WVS wave 7 in October and November 2018 made use of digital communication technologies to obtain information about events in their country and the world in general.

Much of the scholarship about Kazakhstan's digital landscape has changed significantly in recent years, so much so that scholarship on Internet culture in the country published five years ago barely reflects the current situation. Internet access in Kazakhstan rose from 3 percent of the population in 2005 to 31 percent in 2010 and then climbed to 80 percent of the country in 2018 (World Bank 2019). Between 2018 and 2021, the number of active social media users doubled from almost 6 million to 12 million and the number of mobile connections in Kazakhstan in 2018 was equivalent to 144 percent of the total population in Kazakhstan (Kemp 2021). According to the Central Asian Barometer survey wave 4 (Central Asia Barometer Data, Kazakhstan, Wave 4 2018), more than 95 percent of their Kazakh interviewees owned a cell phone in the autumn of 2018. More than 70 percent were using their mobile phone to access the Internet and 68 percent used the Internet to $\log$ on to social media platforms on a daily basis (for more details, see Figure A2 in Appendix A).

The WVS 7 country data on Kazakhstan confirms the trends identified by the Central Asian Barometer survey in as much as it finds that the device most frequently used by Muslim Kazakhs to obtain information online in autumn 2018 was their mobile phone. Table 2 below illustrates the frequency of Muslim Kazakh's use of various technologies to access information online. Overall, more than 60 percent of respondents, irrespective of age or gender, made use of their mobile phone on a daily or weekly basis in 2018. Yet, women seemed to use their mobile phone slightly more frequently (4 percent) than their male colleagues. While almost 40 percent reported never using social media networks to access information online, the highest social media penetration was found among the country's youngest adult cohort, the so-called "Nazarbayev generation" (Laruelle 2019, p. 1), the generation that was born during Nursultan Nazarbayev's rule. Moreover, urban Muslim Kazakhs were more than 30 percent more likely to access social media 
platforms to get information on local and international news than their counterparts in the countryside in 2018. A similar urban/rural divide can be observed for Internet and smartphone penetration. Moreover, divorced and childless Muslim Kazakhs were more likely to use ICTs to read online news than their married counterparts with children. A possible explanation for this is that unwed people who do not face childcare duties have more time to go online and therefore engage more often in online interpersonal communication.

Table 2. Descriptive statistics of Kazakhs' use of various communication technologies to obtain information (Haerpfer et al. 2020).

\begin{tabular}{|c|c|c|c|}
\hline & Internet & Social Media & Mobile Phone \\
\hline Daily & $41.1 \%$ & $33.2 \%$ & $47.5 \%$ \\
\hline Weekly & $16.7 \%$ & $11.1 \%$ & $12.6 \%$ \\
\hline Monthly & $7.7 \%$ & $7.5 \%$ & $7.2 \%$ \\
\hline Less than monthly & $8.4 \%$ & $9.1 \%$ & $10.7 \%$ \\
\hline Never & $25.8 \%$ & $39.1 \%$ & $21.9 \%$ \\
\hline Women * & $57.8 \%$ & $44.6 \%$ & $62.2 \%$ \\
\hline Men * & $58.4 \%$ & $43.8 \%$ & $58.0 \%$ \\
\hline 18-29 years old * & $68.0 \%$ & $59.2 \%$ & $72.8 \%$ \\
\hline 30-49 years old * & $58.2 \%$ & $45.8 \%$ & $60.2 \%$ \\
\hline $50+$ years old * & $49.3 \%$ & $28.1 \%$ & $49.3 \%$ \\
\hline Married * & $57.4 \%$ & $42.9 \%$ & $60.4 \%$ \\
\hline Divorced * & $69.4 \%$ & $53.1 \%$ & $63.3 \%$ \\
\hline Single * & $55.9 \%$ & $44.9 \%$ & $58.3 \%$ \\
\hline Parent * & $54.6 \%$ & $39.4 \%$ & $56.3 \%$ \\
\hline Childless* & $71.1 \%$ & $62.0 \%$ & $74.4 \%$ \\
\hline Urban * & $71.7 \%$ & $60.3 \%$ & $78.8 \%$ \\
\hline Rural * & $43.2 \%$ & $26.7 \%$ & $39.9 \%$ \\
\hline
\end{tabular}

${ }^{*}$ Use of ICTs on a daily or weekly basis.

In summary, the descriptive results presented in Table 2 above, suggest that young, urban, childless, single Muslim Kazakhs were more frequently exposed to content promoting extramarital affairs and divorce on ICTs than older, rural, married Muslim Kazakhs with kids in late 2018.

Table 3 presents models designed to test one of the principal hypotheses of this paper, namely that Muslim Kazakhs' exposure to information on the Internet, mobile phone, and social media has a positive influence on their acceptance of divorce in their community. The results of these analyses are presented in Table 3. As the first column in Table 3 shows, female gender, urban, and age 30-49 correlate significantly and positively with Muslim Kazakhs' approval of divorce. The correlations are significant at the $p<0.05$ level. They suggest that female Muslim Kazakhs in their thirties and forties who live in urban areas were therefore more supportive of divorce than their male counterparts in their twenties and late teens who lived in the countryside in the autumn of 2018. The findings in Table 3 for the variables of female gender, age, and urban support previous observations on divorce demographics in Kazakhstan (Nurbai 2020) in highlighting that women and urban Kazakhs were more likely to file for divorce than men and their counterparts in the countryside in 2018. 
Table 3. Regression analysis for the impact of ICTs on divorce.

\begin{tabular}{|c|c|c|c|}
\hline & Internet & Mobile Phone & Social Media \\
\hline Intercept & $\begin{array}{c}2.786^{* * *} \\
(0.434)\end{array}$ & $\begin{array}{c}2.616^{* * *} \\
(0.433)\end{array}$ & $\begin{array}{c}3.019 * * * \\
(0.426)\end{array}$ \\
\hline Gender & $\begin{array}{l}0.656^{*} \\
(0.257)\end{array}$ & $\begin{array}{l}0.642 * \\
(0.257)\end{array}$ & $\begin{array}{c}0.679 * * \\
(0.256)\end{array}$ \\
\hline Age: $30-49$ & $\begin{array}{l}0.724 * \\
(0.352)\end{array}$ & $\begin{array}{l}0.741 \text { * } \\
(0.352)\end{array}$ & $\begin{array}{l}0.675 \text { * } \\
(0.351)\end{array}$ \\
\hline Age: $50-91$ & $\begin{array}{c}0.395 \\
(0.411)\end{array}$ & $\begin{array}{c}0.401 \\
(0.410)\end{array}$ & $\begin{array}{c}0.297 \\
(0.410)\end{array}$ \\
\hline Education & $\begin{array}{c}0.051 \\
(0.283)\end{array}$ & $\begin{array}{c}0.047 \\
(0.282)\end{array}$ & $\begin{array}{c}0.057 \\
(0.281)\end{array}$ \\
\hline Lower Middle Class & $\begin{array}{c}0.307 \\
(0.303)\end{array}$ & $\begin{array}{c}0.318 \\
(0.302)\end{array}$ & $\begin{array}{c}0.281 \\
(0.301)\end{array}$ \\
\hline Working Class & $\begin{array}{c}0.441 \\
(0.325)\end{array}$ & $\begin{array}{c}0.455 \\
(0.324)\end{array}$ & $\begin{array}{c}0.420 \\
(0.323)\end{array}$ \\
\hline Divorced & $\begin{array}{c}0.593 \\
(0.444)\end{array}$ & $\begin{array}{c}0.559 \\
(0.442)\end{array}$ & $\begin{array}{l}0.665 * \\
(0.440)\end{array}$ \\
\hline Single & $\begin{array}{l}-0.159 \\
(0.407)\end{array}$ & $\begin{array}{l}-0.088 \\
(0.407)\end{array}$ & $\begin{array}{l}-0.258 \\
(0.405)\end{array}$ \\
\hline Childless & $\begin{array}{c}0.324 \\
(0.434)\end{array}$ & $\begin{array}{c}0.234 \\
(0.434)\end{array}$ & $\begin{array}{c}0.474 \\
(0.432)\end{array}$ \\
\hline Urban & $\begin{array}{l}0.541 * \\
(0.275)\end{array}$ & $\begin{array}{c}0.400 \\
(0.286)\end{array}$ & $\begin{array}{l}0.710 * \\
(0.275)\end{array}$ \\
\hline Frequent Internet User & $\begin{array}{l}-0.013 \\
(0.269)\end{array}$ & & \\
\hline Frequent Smartphone User & & $\begin{array}{c}0.385 \\
(0.282) \\
\end{array}$ & \\
\hline Frequent Social Media User & & & $\begin{array}{c}-0.668 \text { * } \\
(0.268)\end{array}$ \\
\hline $\mathrm{R}^{2}$ & 0.039 & 0.042 & 0.049 \\
\hline Adj. $R^{2}$ & 0.020 & 0.023 & 0.031 \\
\hline Num. obs. & 578 & 578 & 578 \\
\hline
\end{tabular}

In contrast to previous studies on divorce, university education, childless, or class are not associated with Muslim Kazakhs' acceptance of marriage annulment. The findings reflect the extent to which patriarchal and religious values and heteronormative behavior patterns that prioritize marriage and reproduction (Beyer and Finke 2019, p. 318) are embedded in Kazakhstan's social norms such that these other traits (respondents' childcare responsibilities, level of education, and class) do not correlate with approval of divorce. Yet, when we control for Muslim Kazakhs' exposure to social media, respondents who had already experienced a divorce were unsurprisingly more likely to support a legal dissolution of a marriage in 2018 (significant at the $p<0.05$ level). Finally, only Muslim Kazakhs' frequent use of social media for information purposes is significantly and negatively related to their approbation of divorce (significant at the $p<0.05$ level). This suggests that Muslim Kazakhs who were exposed to information on social media platforms on a daily and weekly basis tended to agree less with people's wish to file for divorce than their counterparts who were not on social networks in 2018. The findings contradict to a certain degree a previous survey's observation (Nurbai 2020) which found that Kazakhstanis' exposure to social media seems to increase their likelihood to support divorce. In short, rather than exposure to liberal gender norms on ICTs, it was their marital status, as well as their gender, age, 
and place of residence that positively influenced Muslim Kazakhs' approval of divorce in autumn 2018. Being exposed to digital information does not inevitably increase their tendency to register divorce in Kazakhstan.

Whereas frequent exposure to social media was observed to negatively affect Muslim Kazakhs' approbation of marriage annulment, it does not significantly correlate with respondents' approval of casual sex (see column 3 in Table 4). Yet, respondents' frequent consumption of information on the Internet is significantly and positively related to their approval of casual sex (significant at the $p<0.05$ level). Muslim Kazakhs who are exposed to information on the Internet on a daily and weekly basis, therefore, were more likely to support casual sex in 2018. In contrast to previous scholarships' forecast, older respondents (30 plus) were slightly more likely to approve casual sex than the youngest age cohort, the Nazarbayev generation (significant at $p<0.05$ level). Yet, gender, university education, marital status, or class are not associated with respondents' appropriation of casual sex.

Table 4. Regression analysis for the impact of ICTs on casual sex.

\begin{tabular}{|c|c|c|c|}
\hline & Internet & Mobile Phone & Social Media \\
\hline Intercept & $\begin{array}{c}2.002^{* * *} \\
(0.335)\end{array}$ & $\begin{array}{c}2.072 * * * \\
(0.335)\end{array}$ & $\begin{array}{c}2.312 * * * \\
(0.431)\end{array}$ \\
\hline Gender & $\begin{array}{l}-0.019 \\
(0.199)\end{array}$ & $\begin{array}{l}-0.037 \\
(0.199) \\
\end{array}$ & $\begin{array}{l}-0.023 \\
(0.200)\end{array}$ \\
\hline Age: $30-49$ & $\begin{array}{l}0.546 * \\
(0.271)\end{array}$ & $\begin{array}{l}0.537 * \\
(0.271)\end{array}$ & $\begin{array}{c}0.494 \\
(0.272)\end{array}$ \\
\hline Age: $50-91$ & $\begin{array}{l}0.624 * \\
(0.316)\end{array}$ & $\begin{array}{c}0.612 \\
(0.316)\end{array}$ & $\begin{array}{c}0.573 \\
(0.319)\end{array}$ \\
\hline Education & $\begin{array}{c}0.179 \\
(0.217)\end{array}$ & $\begin{array}{c}0.205 \\
(0.217)\end{array}$ & $\begin{array}{c}0.215 \\
(0.218)\end{array}$ \\
\hline Lower Middle Class & $\begin{array}{c}0.068 \\
(0.237) \\
\end{array}$ & $\begin{array}{c}0.045 \\
(0.237) \\
\end{array}$ & $\begin{array}{c}0.020 \\
(0.238) \\
\end{array}$ \\
\hline Working Class & $\begin{array}{c}0.293 \\
(0.249)\end{array}$ & $\begin{array}{c}0.294 \\
(0.250)\end{array}$ & $\begin{array}{c}0.278 \\
(0.250) \\
\end{array}$ \\
\hline Divorced & $\begin{array}{l}-0.617 \\
(0.344)\end{array}$ & $\begin{array}{l}-0.566 \\
(0.343)\end{array}$ & $\begin{array}{l}-0.511 \\
(0.344)\end{array}$ \\
\hline Single & $\begin{array}{l}-0.048 \\
(0.312)\end{array}$ & $\begin{array}{l}-0.052 \\
(0.314) \\
\end{array}$ & $\begin{array}{l}-0.150 \\
(0.313)\end{array}$ \\
\hline Childless & $\begin{array}{l}-0.083 \\
(0.334)\end{array}$ & $\begin{array}{l}-0.075 \\
(0.336) \\
\end{array}$ & $\begin{array}{c}0.058 \\
(0.337) \\
\end{array}$ \\
\hline Urban & $\begin{array}{l}-0.079 \\
(0.213)\end{array}$ & $\begin{array}{l}-0.079 \\
(0.219)\end{array}$ & $\begin{array}{c}0.101 \\
(0.214)\end{array}$ \\
\hline Frequent Internet User & $\begin{array}{l}0.470 * \\
(0.211)\end{array}$ & & \\
\hline Frequent Smartphone User & & $\begin{array}{c}0.351 \\
(0.217) \\
\end{array}$ & \\
\hline Frequent Social Media User & & & $\begin{array}{l}-0.216 \\
(0.212)\end{array}$ \\
\hline $\mathrm{R}^{2}$ & 0.027 & 0.023 & 0.020 \\
\hline Adj. $R^{2}$ & 0.008 & 0.004 & 0.001 \\
\hline Num. obs. & 569 & 569 & 569 \\
\hline
\end{tabular}


Broadly speaking, the evidence presented here only partially supports the hypothesis that Muslim Kazakhs are more likely to approve divorce and casual sex in their society through frequent consumption of information online: on the one hand, frequent social media users tended to disapprove practices of divorce, whereas frequent Internet users were at the same time more likely to approve casual sex. The results suggest that the power of traditional social norms regarding marriage and divorce runs really deep in Kazakh society. Even if instant messaging tools reduce the costs of divorce and increase opportunities for finding an alternative partner, Muslim Kazakhs are not going to engage in extramarital affairs that could escalate into divorce.

\section{Focus Groups Analysis}

In general, focus groups organized by both scholars frequently revealed the perception that information communication technologies (ICTs) have a negative influence on people's morals, even if some of the positions were nuanced.

In Scholar \#2's focus groups, most discussions about divorce were connected to the issue of polygyny and whether or not a man who wants to take a second wife should simply divorce his first wife in order to remarry or if a woman whose husband takes a second wife should file for divorce instead of accepting to share her husband. Yet, there were instances where the issue of divorce was discussed as a separate topic and in connection to ICTs. In Kyzylorda, when asked whether or not family values were changing in Kazakhstan, one female participant answered that they were degrading and mostly blamed the upbringing of children currently who were not listening to their father because they "are all obsessed with the Internet". She lamented the poor discipline of younger generations and the absence of respect between husband and wife, parents and children. She made a connection between Internet use, loose morals, and divorce because "nothing was sacred anymore". Her views echoed other participants' views from different focus groups in Shymkent ${ }^{7}$ and $\mathrm{Aktau}^{8}$. Yet, someone in the same group later associated social media with freedom of speech and thought that young people today were more alert and more resourceful because of their access to the Internet. ${ }^{9}$

As mentioned earlier, divorce is fairly common in Kazakhstan and divorcees do not necessarily face social stigma even if divorce in itself is perceived negatively as shown by survey results presented earlier. At the exception of one young male (unmarried) in his twenties in Nur-Sultan who mentioned that divorce was not a bad thing because it represented a way out for people in unhappy relationships ${ }^{10}$, a majority of focus group participants in their thirties, forties, fifties, and sixties expressed negative opinions about divorce. More importantly, increasing divorce rates were understood as an unwanted consequence of changing family values, a perceived cultural degeneration as well as the use of ICTs. Scholar \#1 observed similar trends among male Kazakhs in Shymkent ${ }^{11}$ and Aktau $^{12}$.

In many instances, focus groups participants specifically highlighted the fact that social media allows individuals to get in touch with new people and flirt effortlessly, which might eventually lead to cheating and escalate in divorce, and their assumptions matched those of divorcees surveyed in 2019 who also identified social media as the third most important reason for divorce (Nurbai 2020). Furthermore, the results from the statistical analysis prove them right to some extent. For some respondents, access to the Internet provided too many opportunities to meet new people and potentially develop feelings for them. In Almaty, one female participant in her forties ${ }^{13}$ mentioned that many young girls have poor values today and are too influenced by the rich celebrities they see online. In her opinion, young women were lazy so they use social media to meet rich men who can provide for them financially. Other participants agreed that this was the reason so many men got mistresses and divorced. In this context, participants in the focus groups organized by Scholar \#1 often argued that the interpersonal interaction online is boosting young Kazakh women's desire to get married to foreigners. Whereas people in their late thirties, forties, and fifties, strictly opposed interethnic marriages between female Kazakhs 
and non-Kazakhs ${ }^{14}$, university-educated female Kazakh youth ${ }^{15}$ welcomed the growing number of "international" and "interethnic marriages" in Kazakhstan, as the excerpt below from a focus group discussion ${ }^{16}$ with banking employees in Aktau demonstrates.

Gaisha: "I think it is good that our cultural habits are changing through the contact with foreigners on social media sites. Thanks to this, we have many international couples today in Kazakhstan. Most couples remain together. However, in particular women fear that relatives oppose their decision to get married to a non-Kazakhstani. My personal opinion is that we live in a free country and that we have the right to fall in love with whomever we want to. (...) I believe that these mixed racial marriages will increase because people learn about other peoples' lifestyles on Instagram and Facebook. Moreover, peoples' approval of interethnic marriages differs across the different regions in Kazakhstan. Some families are more open towards such things and others are not ready to accept them".

Zarina: "These people are fossils [refers to people who reject interethnic marriages]! Cultured (civilized) people will embrace them".

Yet, while the growing number of inter-ethnic marriages was welcomed by young, female, university-educated respondents, discussions of male-only groups such as in Kyzylorda ${ }^{17}$ and $\mathrm{Aktau}^{18}$ mostly focused on the negative influence of the Internet, computers, and phones on peoples' moral upbringing and interpersonal relationships. A jurist ${ }^{19}$ in his early forties complained that people did not read books anymore and only spent time on their phones, ignoring the world around them. The absence of face-to-face communication was to blame for the worsening of relationships. Speculating a bit further, he even mentioned that unequal access to electronic devices might also become a source of conflict and eventually lead to divorce. He described a hypothetical scenario in which a husband has a tablet and his wife does not so she insists that he buys one for her but he refuses. They fight over that and eventually end up divorcing. This improbable sequence of events is far-fetched but it reveals something about the negative perception that some people have toward electronic devices and time spent surfing the Internet. Another male participant ${ }^{20}$ in his sixties went as far as pointing out that divorce has unintended, horrific consequences and that it has been proven that maniacs and killers often come from incomplete families in which the father is absent.

Interestingly, focus groups participants from Nazarbayev University did not address the causes of divorce nor did they emphasize the influence of ICTs in socio-political dynamics in Kazakhstan. Nazarbayev University is a state-funded university that is located in the capital city of Nur-Sultan and which is very international in nature. The education is provided exclusively in English and a majority of the faculty members are foreigners. It is considered to be a very liberal university in Kazakhstan. Unlike other participants from the "general population", they did not spontaneously make connections between changing family values and divorce, nor ICTs. University-educated Kazakh youths' own liberal mindsets (Bigozhin 2019) and frequent use of ICTs could explain why they did not raise these issues. However, it is also possible that divorce appeared to be of no concern to them because of their young age and the fact that most of them were not married. Apart from one focus group with female students at a local university in Almaty ${ }^{21}$, who linked their frequent use of social media with Kazakh women's right to file for divorce, similar tendencies regarding university-educated Kazakh youth were observed by Scholar \#1 in Shymkent ${ }^{22}$ and $\mathrm{Aktau}^{23}$.

Generally speaking, focus group participants in their forties, fifties, and sixties, both men and women from the South as well as the North, highlighted a negative relationship between the use of electronic devices, time spent on the Internet, and the quality of interpersonal relationships, in particular, marriage. For them, online communication was damaging marriage because firstly, it gives opportunities to meet new people and have extramarital affairs (engage in casual sex), and secondly, it undermines existing love relationships by reducing real, genuine interactions. There seems to be a gap between generations however with young people, and in particular young university-educated women finding divorce 
and ICTs usage less problematic. The interview data, therefore, confirm to some extent the assumption of the statistical analysis that frequent exposure to the Internet can be expected to increase Kazakhs' likeliness to engage in casual sex. In addition, the predicted negative influence of frequent social media use on Kazakhs' appropriation of divorce seems to be validated. Finally, in line with the statistical analysis, the data arising from focus groups highlight that female Muslim Kazakh youth seem to display more welcoming attitudes towards the growing number of divorces in Kazakhstan. Apart from university-educated Kazakh youth, their less-educated peers and older generations (30+) argued that the utilization of social media platforms has a negative influence on marriages, because they allow people to engage with alternative partners easily and cheaply and as a result people are more likely to cheat on their spouse and even file for divorce.

\section{Conclusions}

Since independence thirty years ago, Kazakhstani society has experienced protracted and extensive socio-political changes due to the reorganization of political authority, the advent of capitalism, and the growing influence of globalization. These transformations are likely to affect diverse social institutions, including marriage. It nevertheless remains central to peoples' lives considering that marriage rates are extremely high and that an overwhelming majority of Kazakhstanis envision their future-self as married with children. Nationalizing discourses that promote heteronormative family values contribute to strengthening the institution of marriage. However, in oil-rich Kazakhstan, competing gender norms also challenge the traditional institution of marriage and relationships. As a result, casual sex before marriage appears fairly common and divorce rates increase at a fast rate. Early marriages, domestic violence, and increasing tolerance towards parental interference are often evoked to explain the increasing number of divorces. In addition, people tend to blame social media for disrupted marriages and separations. Therefore, we were interested in exploring the link between social media usage and approval of divorce and casual sex.

Overall, the findings from the statistical and non-statistical analysis show that frequent exposure to information on the Internet and social media does not necessarily increase Muslim Kazakhs' approval of divorce and casual sex. The reported findings illustrate that the traditional family values are deep-seated in Kazakh society. Yet, there seems to be a gap between people's ideals representations of relationships and their individual behavior given the high divorce rates and involvement in casual sex. What people say in surveys, and especially focus group discussions, often diverges from what they actually believe. These statements are often biased toward normative beliefs. We have also argued that traditional values are being challenged by competing narratives that people are exposed to online.

Data from the statistical analysis and the focus groups revealed differences of opinion between people from the large urban centers (Nur-Sultan and Almaty) in comparison to participants from cities located in regions understood as more socially conservative (Kyzylorda and Shymkent). There are indeed strong regional variations that need to be accounted for. In general, divorce is a lot more common in urban areas and there are also many regional particularities. We find the highest divorce rates in the northern regions of Pavlodar and Kostanay as well as in Nur-Sultan and Almaty. In contrast, Kyzylorda and Shymkent have some of the lowest divorce rates in the country (KISD 2020, p. 293). In this paper, we considered the opinions of Muslim "ethnic Kazakhs" only because they made the bulk of our focus groups participants and therefore, we are unable to account for variations in terms of ethnicity. It is probably no coincidence that the northern regions which have the highest divorce rates are mostly populated by Orthodox "ethnic Russians" who tend to have different marital practices. 
Furthermore, both the findings from the statistical analysis and the focus groups confirm previous scholarship's assumption that female Muslim Kazakh youth seems to display a more welcoming attitude towards the growing number of divorces than their male and older peers. In short, frequent ICTs consumption seems to not only cause a generational divide, but also a gender divide.

However, we are cautious in drawing any definite conclusion from our findings. One specific reason is that the statistical analysis did not reveal what type of information obtained on ICTs affects Muslim Kazakhs' approbation of divorce and casual sex. Having established that social media and Internet consumption contributes to shaping individuals perception or understanding of certain issues-in this case, divorce and casual sex-it is difficult to identify a precise correlation, simply because we do not know the kind of content people consume online. A lot of digital content is determined by algorithms showing content that matches users' interests and world views, which inevitably results in circular thinking. This selective consumption is further enhanced by Instagram and Facebook's "shadow ban" (Are 2020, p. 742) that targets sexually suggestive content in particular. Furthermore, many social media users produce nationalist content that promotes national values, including traditional family values. In fact, time spent on social media might in some cases reinforce gender stereotypes and a traditional understanding of marriage obligations rather than challenge them. Regardless of the tangent, the statistics and the narratives from focus groups revealed that the consumption of online content and time spent on the Internet has an impact on social understanding of dating, marriage, and divorce in Muslim Central Asia.

Author Contributions: Conceptualization, J.D. and H.T.; methodology, J.D. and H.T.; software, J.D.; validation, J.D.; formal analysis, J.D. and H.T.; investigation, H.T. and J.D.; resources, J.D. and H.T.; data curation, J.D. and H.T.; writing-original draft preparation, J.D. and H.T.; writing-review and editing, J.D. and H.T.; visualization, J.D.; supervision, J.D. and H.T.; project administration, J.D. and H.T.; funding acquisition, J.D. and H.T. Both authors have read and agreed to the published version of the manuscript.

Funding: Hélène Thibault's research was funded under the Small Grants at Nazarbayev University, grant number: 110119FD4505. Jasmin Dall'Agnola's fieldwork in Kazakhstan was made possible by the financial support of two granting offices: her PhD host institution, Oxford Brookes University, who awarded her PhD research a three-year, full-time university research grant, and the British Association for Slavonic and East European Studies (BASEES), who supported her field research trip to Kazakhstan in the summer of 2019 with a generous postgraduate research grant.

Institutional Review Board Statement: The study was conducted according to the guidelines of the Declaration of Helsinki, and approved by the Research Ethics Committee of Oxford Brookes University (protocol code 181240, 8 November 2018) and the Institutional Research Ethics Committee (IREC) of Nazarbayev University (8 August 2017).

Informed Consent Statement: Informed consent was obtained from all subjects involved in the study.

Data Availability Statement: The data presented in this study are contained within the article.

Conflicts of Interest: The authors declare no conflict of interest. 


\section{Appendix A}

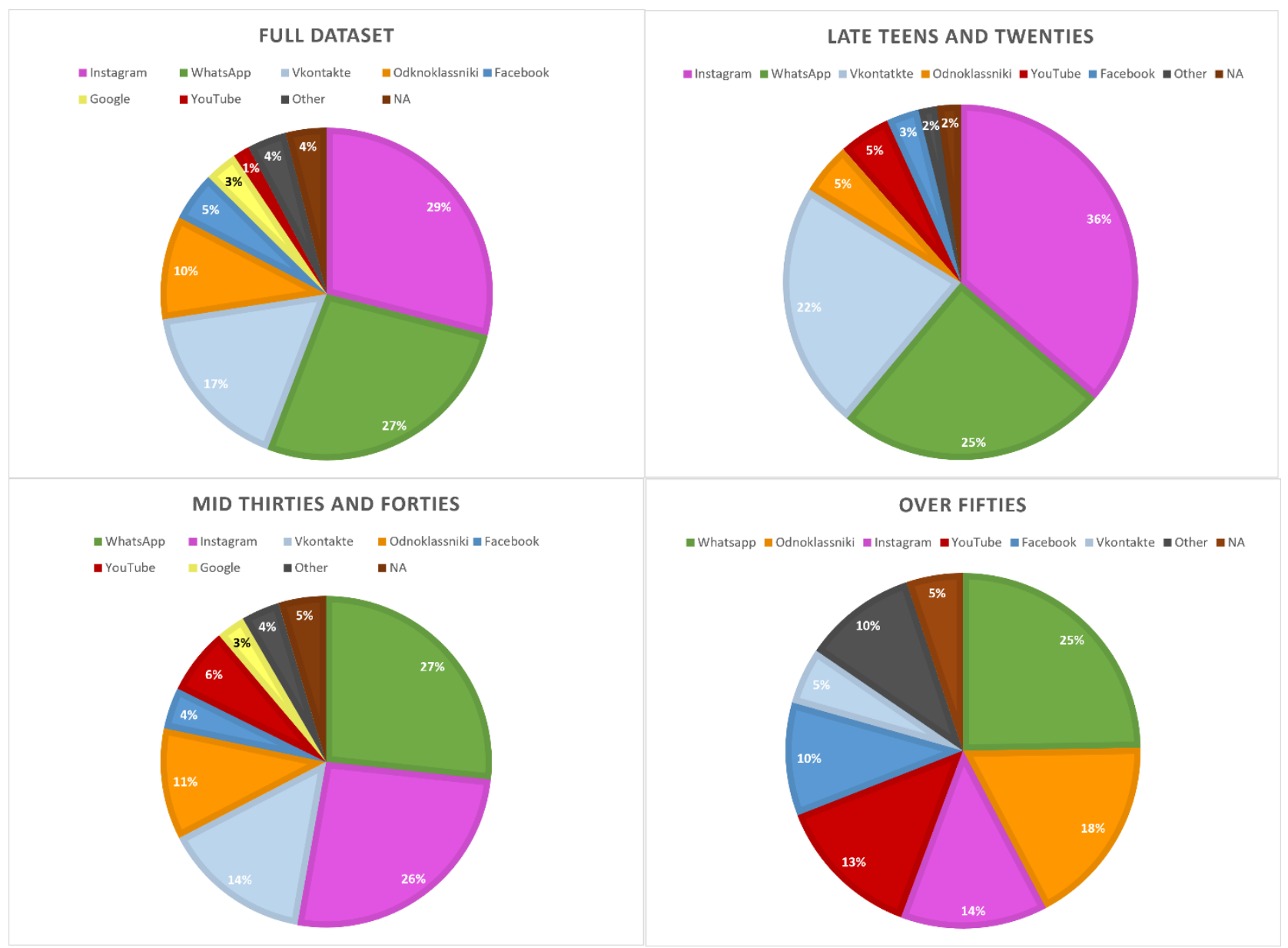

Figure A1. Kazakhs' social media preferences in autumn 2018 (Central Asia Barometer Data, Kazakhstan, Wave 4 2018).

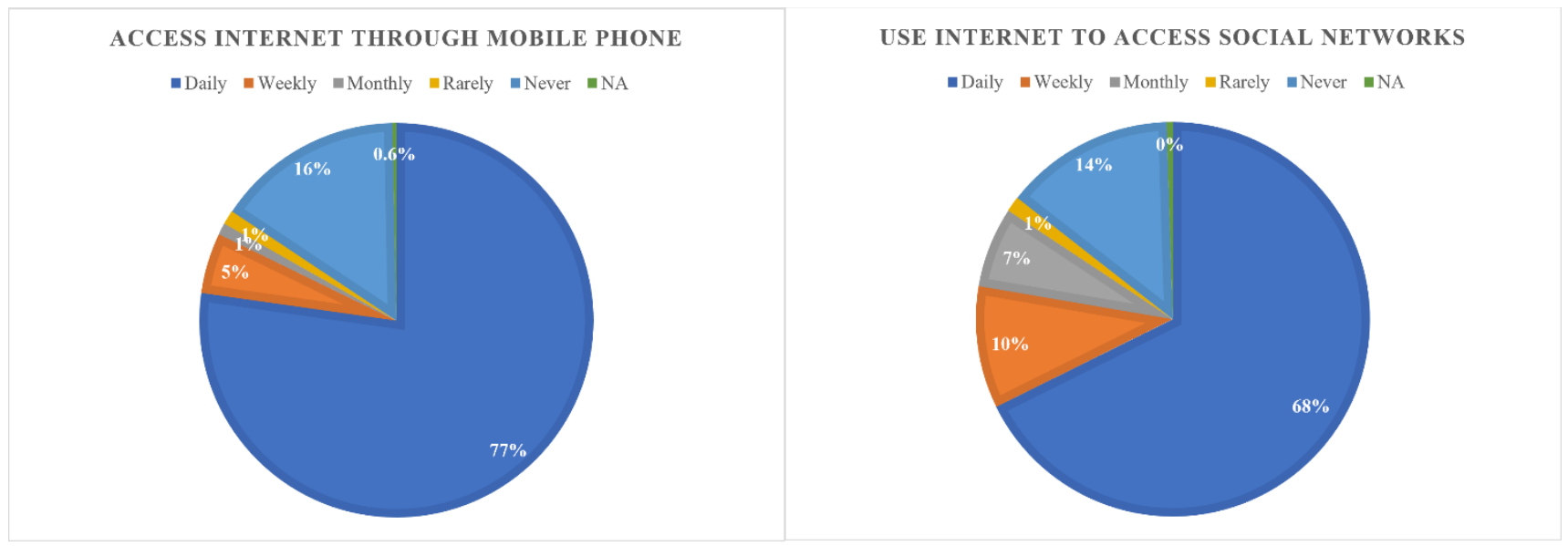

Figure A2. Kazakhs' access option to Internet and social media in autumn 2018 (Central Asia Barometer Data, Kazakhstan, Wave 4 2018). 


\section{Notes}

1 Kazakhstan is a multiethnic country and in this article, Kazakhstanis refer to all citizens of Kazakhstan, regardless of their ethnic identity and Kazakhs to those who self-identify as "ethnic Kazakhs". As a result of Soviet colonization, ethnic identities were crystallized in official documents and remained a strong identity marker. The people interviewed for this article all self-identified as Kazakhs and Muslims.

2 Homosexuality was even criminalized during long periods of time in the USSR (Kon 1995).

3 http://www.oecd.org/els/family/database.htm (accessed on 14 July 2021).

4 In both the Russian as well as the Kazakh WVS 7, survey respondents were asked to what extent they believe that divorce [Razvod (Russian), Azhyrasu (Kazakh)] or casual sex [Sluchaĭnye seksualnye svyazi (Russian), Kezdeĭsok seksualdy baŭlanystar (Kazakh)] are justified [V Kakou stepeni eto deřstvie, na Vash vzglyiad, mozhet byt' opravdano? (Russian). Sonymen, kanshalykty oryndy dep oŭlă̌syz? (Kazakh).]

5 Zheng et al. (2017), in their study on online sexual activity in China, found that married people were more likely to engage in online sexual activities and therefore had more experience in online sexual activities than single people.

$6 \quad$ Ninety One is a popular boys band, inspired by Korean pop music (known as Q-pop in Kazakhstan). Their androgynous looks and colorful outfits made them very unpopular among conservative circles in Kazakhstan, who accused them of insulting national culture (Tan 2021).

7 FG 18, male participant aged 58, Shymkent/FG 19, female participant aged 43, Shymkent.

$8 \quad$ FG 4, female participant aged 59, Aktau.

9 FG 16, female participants aged between 22 and 45, Kyzylorda.

10 FG 11, unmarried male participant aged 24, Nur-Sultan.

11 FG 18, male participant aged 58, Shymkent.

12 FG 3, male Kazakhs aged 32 and 33, Aktau/FG 2, male Kazakh aged 24, Aktau.

13 FG 8, female participant aged 42, Almaty.

14 FG 4, female participants aged 29, 37 and 59, Aktau/FG 19, female participants aged 28 and 43, Shymkent.

15 FG 5, female students aged 22, 23 and 23, Almaty/FG 20, female students aged 23, 29, Shymkent/FG 1, female students aged 19 and 20, Aktau.

16 FG 2, female participants aged 26 and 26, Aktau

17 FG 17, male participants aged between 22 and 42, Kyzylorda.

18 FG 3, male participants aged 32 and 33, Aktau.

19 FG 17, male participant aged 41, Kyzylorda.

20 FG 9, male participant aged 60, Nur-Sultan.

21 FG 5, female students aged 22, 23 and 23, Almaty.

22 FG 20, female students aged 23, 29, Shymkent.

23 FG 1, female students aged 19 and 20, Aktau.

\section{References}

Are, Carolina. 2020. How Instagram's Algorithm is Censoring Women and Vulnerable Users but Helping Online Abusers. Feminist Media Studies 20: 741-44. [CrossRef]

Arystanbek, Aizada. 2020. Trapped between East and West: A Study of Hegemonic Femininity in Kazakhstan's Online and State Discourses. Master's Thesis, Central European University, Budapest, Hungary.

Beyer, Judith, and Peter Finke. 2019. Practices of Traditionalization in Central Asia. Central Asian Survey 38: 310-28. [CrossRef]

Bigozhin, Ulan. 2019. We Love Our Country in Our Own Way: Youth, Gender \& Nationalism. In The Nazarbayev Generation. Youth in Kazakhstan. Edited by Marlene Laruelle. New York: Lexington Books, pp. 115-32.

Blum, Douglas. 2016. The Social Process of Globalization. Return Migration and Cultural Change in Kazakhstan. Cambridge: Cambridge University Press.

Blum, Douglas. 2019. Return Migration from the United States: Exploring the Dynamics of Cultural Change. In The Nazarbayev Generation. Youth in Kazakhstan. Edited by Marlene Laruelle. New York: Lexington Books, pp. 213-25.

Borisova, Elena. 2021. 'Our Traditions Will Kill Us!': Negotiating Marriage Celebrations in the Face of Legal Regulation of Tradition in Tajikistan. Oriente Moderno 100: 147-71. [CrossRef]

Carter, Zackery. 2016. Married and Previously Married Men and Women's Perception of Communication on Facebook with the Opposite Sex: How Communicating through Facebook Can Be Damaging to Marriages. Journal of Divorce E Remarriage 57: 36-55. [CrossRef]

Central Asia Barometer Data, Kazakhstan, Wave 4. 2018. Available online: http:/ / www.ca-barometer.org (accessed on 14 June 2021). 
Chakraborty, Kabita. 2012. Virtual Mate-seeking in the Urban Slums of Kolkata, India. South Asian Popular Culture 10: 197-216. [CrossRef]

Cleuziou, Juliette, and Julie McBrien. 2021. Marriage Quandaries in Central Asia. Oriente Moderno 100: 121-46. [CrossRef]

Cleuziou, Juliette, and Lucia Direnberger. 2016. Gender and Nation in Post-Soviet Central Asia. From National Narratives to Women's Practices. Nationalities Papers 44: 195-206. [CrossRef]

Cleuziou, Juliette. 2021. "What Does Marriage Stand for?" Getting Married and Divorced in Contemporary Tajikistan. Oriente Moderno 100: 248-73. [CrossRef]

Dall'Agnola, Jasmin. 2020. Queer Culture and Tolerance in Kazakhstan. In PC on Earth. The Beginnings of the Totalitarian Mindset. Edited by Jasmin Dall'Agnola and Jabbar Moradi. Stuttgart and New York: ibidem, Columbia University Press, pp. 99-116.

Dall'Agnola, Jasmin. 2021. The Impact of Globalization on National Identities in Post-Soviet Societies. Ph.D. dissertation, Oxford Brookes University, Oxford, UK.

de Lenne, Orpha, Laurens Wittevronghel, Laura Vandenbosch, and Steven Eggermont. 2019. Romantic Relationship Commitment and the Threat of Alternatives on Social Media. Personal Relationships 26: 680-93. [CrossRef]

Fizza, Iqbal, and Jami Humaira. 2019. Effect of Facebook Use Intensity Upon Marital Satisfaction Among Pakistani Married Facebook Users: A Model Testing. Pakistan Journal of Psychological Research; Islamabad 34: 191-213. [CrossRef]

Forbes. 2020. 73\% kazakhstantsev Schitayut Sem'yu Smyslom Zhizni-Sotsissledovaniye (73\% of Kazakhstanis Consider Family to be the Meaning of Life-Social Research). Forbes. May 16. Available online: https://forbes.kz/news/2020/05/16/newsid_225465 (accessed on 14 June 2021).

Friedrich Ebert Foundation Report. 2019, In Tsennosti Kazakhstanskovo obshchestva v sotsiologicheskom izmerenii. Almaty: Deluxe Printery.

Haerpfer, Christian, Ronald Inglehart, Alejandro Moreno, Christian Welzel, Kseniya Kizilova, Jaime Diez-Medrano, Marta Lagos, Pippa Norris, Eduard Ponarin, Bi Puranen, and et al., eds. 2020. World Values Survey: Round Seven-Country-Pooled Datafile. Madrid and Vienna: JD Systems Institute \& WVSA Secretariat. [CrossRef]

Isaacs, Rico. 2019. The Kazakhstan Now! Hybridity and Hipsters in Almaty. Negotiating Global and Local Lives. In The Nazarbayev Generation. Youth in Kazakhstan. Edited by Marlène Laruelle. New York: Lexington Books, pp. 227-43.

Kabatova, Karlygash. 2019a. Overcoming a Taboo. Normalizing Sexuality Education. In The Nazarbayev Generation. Youth in Kazakhstan. Edited by Marlène Laruelle. New York: Lexington Books, pp. 289-304.

Kabatova, Karlygash. 2019b. V Poiskakh Zdravogo Smysla Kakaya Sistema Polovogo Prosveshcheniya Nuzhna Kazakhstanu? Almaty: Soros Foundation Kazakhstan.

Kandiyoti, Deniz. 2007. The Politics of Gender and the Soviet Paradox: Neither Colonized, Nor Modern? Central Asian Survey 26: 601-23. [CrossRef]

Kazakhstan Today. 2018. Every Second Marriage Breaks Down in North of Kazakhstan, and Every Fifth—in South. Kazakhstan Today. October 19. Available online: https://www.kt.kz/eng/society/every_second_marriage_breaks_down_in_north_of_kazakhstan_ and_every_fifth_in_south_1153664437.html (accessed on 14 June 2021).

Keller, Soshana. 2001. To Moscow Not Mecca: The Soviet Campaign against Islam in Central Asia, 1917-1941. Westport: Praeger Publishers.

Kemp, Simon. 2021. Digital 2021: Kazakhstan. Available online: https:/ / datareportal.com/reports/digital-2021-kazakhstan (accessed on 22 June 2021).

Khabar. 2021. Gde v Kazakhstane chashche vsego razvodyatsya i zhenyatsya (Where in Kazakhstan People get Divorced and Married Most Often). Khabar. June 1. Available online: https://24.kz/ru/news/social/item/464747-gde-v-kazakhstane-chashche-vsegorazvodyatsya-i-zhenyatsya (accessed on 14 June 2021).

Khegai, Marina. 2020. Pervyy 'yyat' v istorii: Kak nachali stydit' 100 let nazad. Caravan. June 25. Available online: https://www. caravan.kz/gazeta/pervyjj-uyat-v-istorii-kak-nachali-stydit-100-let-nazad-649436/ (accessed on 14 June 2021).

Kikuta, Haruka. 2019. Mobile Phones and Self-Determination among Muslim youth in Uzbekistan. Central Asian Survey 38: 181-96. [CrossRef]

KISD. 2020. "Kazakhstan Families", Kazakhstan Institute of Public Development «Rukhani zhangyru». Available online: https: / / kipd.kz/ru/2020-kazahstanskie-semi-nacionalnyy-doklad (accessed on 14 June 2021).

Kon, Igor. 1995. The Sexual Revolution in Russia: From the Age of the Czars to Today. New York: The Free Press.

Krueger, Richard, and Mary Casey. 2015. Focus Groups. A Practical Guide for Applied Research. Los Angeles: SAGE.

Kudaibergenova, Diana. 2018. Project 'Kelin': Marriage, Women and Re-Traditionalization in Post- Soviet Kazakhstan. In Women of Asia: Globalization, Development, and Social Change. Edited by Mehrangiz Najafizadeh and Linda Lindsay. London: Routledge, pp. 379-90.

Kudaibergenova, Diana. 2019. The Body Global and the Body Traditional: A Digital Ethnography of Instagram and Nationalism in Kazakhstan and Russia. Central Asian Survey 38: 363-80. [CrossRef]

Laruelle, Marlene. 2019. Introduction: The Nazarbayev Generation: A Sociological Portrait. In The Nazarbayev Generation. Youth in Kazakhstan. Edited by Marlene Laruelle. New York: Lexington Books, pp. 1-21.

Lo, Mbaye, and Taimoor Aziz. 2009. Muslim Marriage Goes Online: The Use of Internet Matchmaking by American Muslims. Journal of Religion and Popular Culture 21. [CrossRef]

Nguyen, Aline. 2020. Love at First Click: Understanding Success in Marriage through the Experience of Online Dating. Ph.D. thesis, Alliant International University, San Diego, CA, USA.

Northrop, Douglas. 2004. Veiled Empire: Gender and Power in Stalinist Central Asia. Ithaca and London: Cornell University Press. 
Nurbai, Rabiga. 2020. Razvody v Kazachstane: Prichiny, tendentsii i vyplata alimentov. strategy2050.kz. July 22. Available online: https://strategy2050.kz/ru/news/razvody-v-kazakhstane-prichiny-tendentsii-i-vyplata-alimentov-/ (accessed on 14 June 2021).

Pourmehdi, Mansour. 2015. Globalization, the Internet and Guilty Pleasures in Morocco. Sociology and Anthropology 3: 456-66. [CrossRef]

Sagadiyeva, Aruzhan. 2021. Social Taboos and Political Legitimation: Debating Polygyny in Post-Soviet Kazakhstan. Master dissertation, Nazarbayev University, Nur-Sultan, Kazakhstan. Available online: http://nur.nu.edu.kz/handle/123456789/5390 (accessed on 14 June 2021).

Sakhova, Gulzat. 2020. Kak vzyskat' alimenty s dolzhnikov obsudili predstaviteli KNPK v Almatinskoy oblasti. Inform. October 12. Available online: https:/ / www.inform.kz/ru/kak-vzyskat-alimenty-s-dolzhnikov-obsudili-predstaviteli-knpk-v-almatinskoyoblasti_a3705159 (accessed on 14 June 2021).

Sharifinia, Azadeh, Maryam Nejati, Mohammad Hossein Bayazi, and Hassan Motamedi. 2019. Investigating the Relationship between Addiction to Mobile Social Networking with Marital Commitment and Extramarital Affairs in Married Students at Quchan Azad University. Contemporary Family Therapy 41: 401-7. [CrossRef]

Smayyl, Meyirim. 2020. 40 protsentov brakov zakanchivayetsya razvodami v Kazakhstane-issledovaniye. Tengri News. February 18. Available online: https:/ / tengrinews.kz/kazakhstan_news/40-protsentov-brakov-zakanchivaetsya-razvodami-kazahstane391959 / (accessed on 14 June 2021).

Sotoudeh, Ramina, Roger Friedland, and Janet Afary. 2017. Digital Romance: The Sources of Online Love in the Muslim world. Media, Culture E Society 39: 429-39. [CrossRef]

Sulaĭmonn, Irshod. 2020. V Tadzhikistane za razvod pa telefony lishat' svobody na budut. Asia-Plus. December 15 . Available online: https:/ / asiaplustj.info/ru/news/tajikistan/society/20201215/v-tadzhikistane-za-razvod-po-telefonu-lishat-svobodine-budut (accessed on 14 June 2021).

Sweet-McFarling, Kristen. 2014. Polygamy on the Web: An Online Community for an Unconventional Practice. Master's Thesis, Colorado State University, Fort Collins, CO, USA.

Tan, Yvette. 2021. The K-Pop Inspired Band That Challenged Gender Norms in Kazakhstan. BBC. January 4. Available online: https: / / www.bbc.com/news/world-asia-55359772 (accessed on 14 June 2021).

Thibault, Hélène. 2021. The Many Faces of Polygyny in Kazakhstan. Central Asia Program 255. Available online: https://www. centralasiaprogram.org/archives/20019\#_ftn22 (accessed on 14 June 2021).

Thibault, Hélène. forthcoming. Online Male Sex Work in Kazakhstan: A Distinct Market? Central Asian Affairs. manuscript accepted.

Titova, Aksiniya. 2020. Kazakhstanskii Rynok Seksual'nykh Uslug Rasshiyaraets (The Kazakhstani Sex Services' Market Is Widening). Moskovskii Komsololets KZ. October 7. Available online: https://mk-kz.kz/social/2020/10/07/kazakhstanskiy-rynokseksualnykh-uslug-rasshiryaetsya.html (accessed on 14 June 2021).

Torno, Svetlana. 2017. Tajik in Content-Soviet in Form? Reading Tajik Political Discourse on and for Women. In The Family in Central Asia: New Perspectives. Edited by Sophie Roche. Berlin: Klaus Schwarz Verlag, pp. 141-61.

UN Demographic Yearbook. 2019. Demographic Yearbook 70th Issue. Available online: https://unstats.un.org/unsd/demographicsocial/products/dyb/dyb_2019/ (accessed on 14 June 2021).

Valenzuela, Sebastián, Daniel Halpern, and James Katz. 2014. Social Network Sites, Marriage Well-Being and Divorce: Survey and State-Level Evidence from the United States. Computers in Human Behavior 36: 94-101. [CrossRef]

We Are Social. 2021. Digital 2021. Global Overview Report. Available online: https://wearesocial.com/digital-2021 (accessed on 22 June 2021).

World Bank. 2019. Individuals Using the Internet (\% of Population)—Kazakhstan. Available online: https://data.worldbank.org/ indicator/IT.NET.USER.ZS?locations=KZ (accessed on 14 June 2021).

Zhang, Jiaping, Mingwang Cheng, Xinyu Wei, and Xiaomei Gong. 2018. Does Mobile Phone Penetration Affect Divorce Rate? Evidence from China. Sustainability 10: 3701. [CrossRef]

Zhdanko, Tatyana, and Klara Basayeva. 1990. Semeynyy byt narodov SSSR. Moscow: Nauka.

Zheng, Lijun, Xuan Zhang, and Yingshi Feng. 2017. The New Avenue of Online Sexual Activity in China: The smartphone. Computers in Human Behavior 67: 190-95. [CrossRef]

Zheng, Shilin, Yuwei Duanb, and Michael Ward. 2019. The effect of Broadband Internet on Divorce in China. Technological Forecasting $\mathcal{E}$ Social Change 139: 99-114. [CrossRef]

Zhulmukhametova, Zharda. 2018. Issledovanie: 2\% devushek do 19 let v Kazakhstane delali aborty v domashnikh usloviyakh. Informburo. December 4. Available online: https:/ /informburo.kz/novosti/issledovanie-2-kazahstanskih-devushek-do-19-letdelali-aborty-v-domashnih-usloviyah.html (accessed on 14 June 2021). 